\title{
Ecological Research Reserve for Brazil's Amazon Rain-forest Established in Ouro Preto do Oeste, Rondônia
}

A 138-ha area of rain-forest has been donated to Brazil's National Institute for Research in the Amazon (INPA) for creation of an ecological research reserve in Ouro Preto do Oeste, Rondônia. The Municipal Council of Ouro Preto do Oeste unanimously approved the donation (Law No. 19 of 12 December 1983). The proposal, submitted to the Council by Ouro Preto do Oeste's Mayor, Sr Expedito Rafael Gões Siqueira, gave the mayor's office authority to make the donation to INPA, which was done on 21 December 1983 (Decree No. 173). The creation act (01-009/84), by means of which INPA officially established the Reserve, was signed in Manaus on 15 February 1984.

Because of its unique location, the Ouro Preto do Oeste Ecological Research Reserve will be particularly valuable for scientists investigating the Amazon rain-forest's delicate ecological relationships. The nearest part of the Reserve is situated only about 500 metres from downtown Ouro Preto do Oeste, a municipal seat and rapidly-growing town. The town, which did not exist in 1970, already had a population of 4,936 in 1980 , and is approximately double that size today. Research workers will be able to stay in Ouro Preto do Oeste-where hotels, restaurants, and other facilities, are readily available-and walk to their study-sites. In the present age of tight research budgets, the savings from this unusually convenient location should mean that many research projects can be done in it that would otherwise be unrealistic without major institutional investments.

Because of the great extent to which the world's rain-forests have been destroyed in areas near to human settlements, a major part of the scientific research in tropical forests has been done in research stations that were built (at significant cost) at the remote sites where protected forest fragments are located. Examples include Finca la Selva in Costa Rica, Barro Colorado Island in Panama, Taï in Ivory Coast, and Pasoh in Malaysia. Other research has been done as a part of ephemeral 'expeditions' to rain-forest areas, or in rustic camps supported by fleets of vehicles from major research institutions. The expensive infrastructure needed to mount research programmes in these traditional ways is unnecessary in the case of Ouro Preto do Oeste, thanks to the presence of the town and the vision shown by its newly-elected government in providing for this Ecological Research Reserve.

The State of Rondônia, located in the corner of Brazil's Amazon region bordering on Bolivia, is the focus of the most explosive deforestation in all of Amazonia. Rondônia serves as a gateway to the Amazon for an increasing flood of migrants who enter the region from southern Brazil, where mechanization of agriculture and concentration of land ownership are

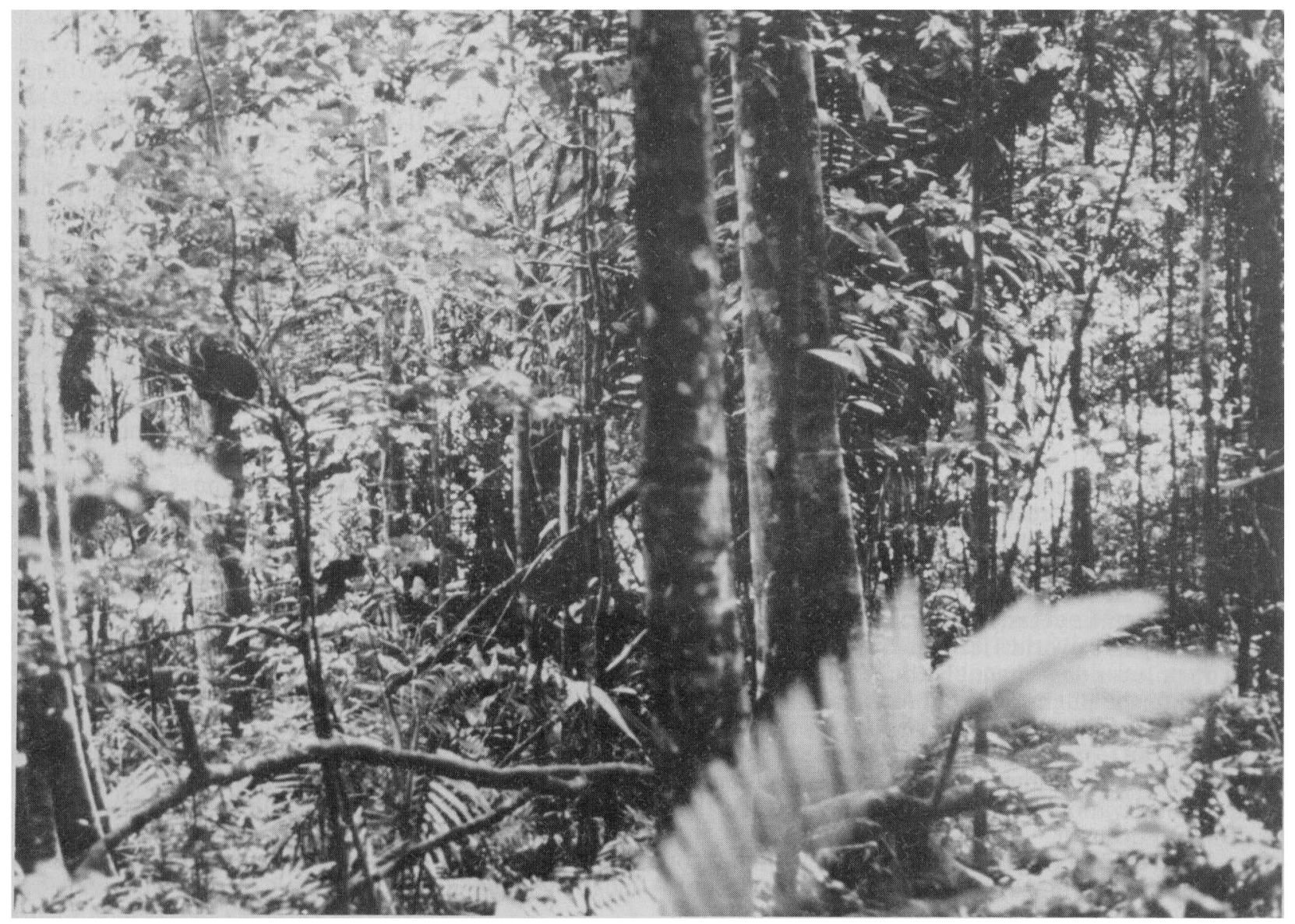

FIG. 1. A view of Amazonian rain-forest in the Ecological Research Reserve established in Ouro Preto do Oeste, Rondônia, Brazil. Photo: Professor Philip M. Fearnside. 


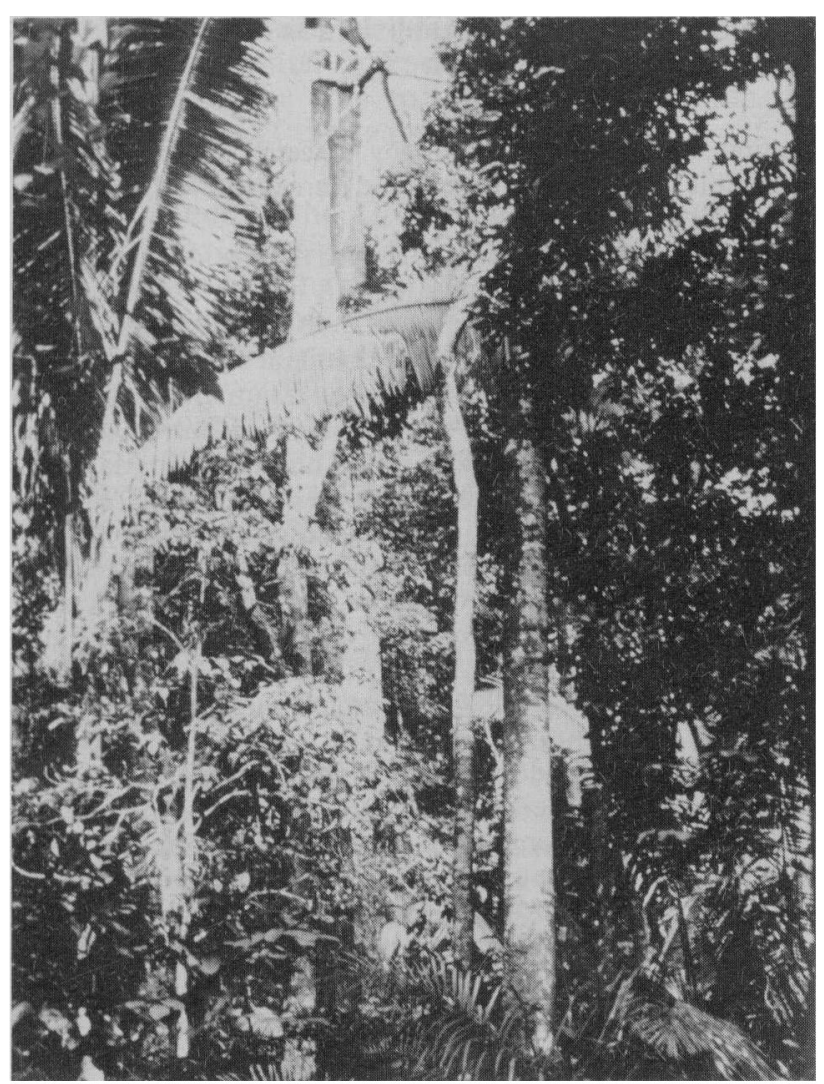

FIG. 2. Another view in the Reserve.

Photo: Professor Philip M. Fearnside. forcing small farmers to leave. Wealthy ranchers and speculators are also attracted to Amazonia, where their land-claims are secured by replacing the rain-forest with cattle pasture. Satellite data show that the deforested area in Rondonia increased from 1,217 sq. $\mathrm{km}$ in 1975 to $4,185 \mathrm{sq} . \mathrm{km}$ in 1978 , and then to 7,579 sq. $\mathrm{km}$ already in 1980 - an exponential rate that threatens to destroy all forests in the State within the present decade if continued unchanged.

The rapid deforestation in Rondônia means that the reserve was created just in time. Steep hills and the proximity of the law-enforcement authorities of Ouro Preto do Oeste have protected the land from invasion by squatters. A recentlyapproved grant from World Wildlife Fund-US will provide for construction of a formidable fence around the area, and for payment of a guard for the Reserve's first year. Construction of the fence, now under way, should be complete by the end of May 1984.

INPA's Director, Dr Henrique Bergamin Filho, has established the internal regulations of the Reserve and appointed an Administrative Council of INPA research workers. As Director of the new Reserve he has chosen the undersigned, who should be contacted by scientists who may be interested in conducting research in the Reserve.

Philip M. FEARNSIDE, Research Professor Departamento de Ecologia

Instituto Nacional de Pesquisas da Amazônia (INPA)

Caixa Postal 478

69.000 Manaus-Amazonas

Brazil.

\section{Wetlands News from IUCN}

Protection of the Dutch sector of the Wadden Sea, an important and vast coastal wetland bordered also by Denmark and the Federal Republic of Germany, has been given international legal status. The announcement was made by Netherlands Minister of Agriculture and Fisheries, Mr G. Braks, at the Second Conference of Parties to the 'Ramsar' Convention, held in Groningen, Netherlands, from 7 to 12 May 1984.

Three countries (Belgium, Costa Rica, and France) pledged themselves to join the Ramsar Convention 'family', which will bring the number of Contracting Parties to 38. Six others, including the USA, said they would give careful consideration to ratifying the Convention in the near future.

Not all the news was good, however: Delegates heard that Malawi had lost five of its 11 important wetlands during the last three years, and the Djoudj National Bird Park in Senegal, a World Heritage Site, is in danger of drying up unless a new channel is built. The Conference responded to the plight of wetlands conservationists in Africa and other Third World regions by calling for action from the Convention secretariat to set up a clearing house to channel money, training, and equipment, to wetland conservation projects-especially in areas that are prone to drought.

The Convention on Conservation of Wetlands of International Importance especially as Waterfowl Habitat, usually called the Ramsar Convention after the town in Iran where it was adopted, entered into force in 1975. The States that are party to the Convention accept the premise that the wise use of wetlands to serve human needs must be compatible with conservation of Nature and natural resources. In addition to a general obligation to conserve wetland areas, each has undertaken to recognize at least one prime wetland on its territory as being of international importance.

The List of Wetlands of International Importance now totals nearly 300 sites occupying some 20 million hectares. If promises made at Groningen are fulfilled, the List could swell to more than 500 sites and the area which it covers could be trebled. Thus, for example, France has pledged to designate the Camargue and many other sites already protected under national legislation, when she ratifies the Convention, while the British delegation announced that 132 sites in the UK will have been added to the List by the end of 1986 .

The Convention is currently serviced, with only token financial support from the 'States Party', by IUCN, with scientific support provided by the International Waterfowl Research Bureau. A Task-Force, composed of representatives of Canada, Denmark or Sweden, the Netherlands, Poland, Senegal, and Tunisia, has been established to help settle the question of the Convention's long-term organization and financing.

$$
\begin{aligned}
& \text { DANIEL NAVID } \\
& \text { IUCN } \\
& \text { World Conservation Centre } \\
& \text { Avenue du Mont-Blanc } \\
& \text { I196 Gland, Switzerland. }
\end{aligned}
$$

